\title{
Renovating Open Shallow Dug Wells for Off-Season Home Gardening in Nepal Terai
}

\author{
Okwany $\mathbf{R}^{1 *}$, Prathapar $\mathbf{S}^{2}$ and Bastakoti $\mathbf{C R}^{\mathbf{1}}$
}

1 International Water Management Institute (IMWI), Kathmandu, Nepal

IInternational Water Management Institute (IWMI), Pelawatte, Battaramulla, Sri Lanka

\begin{abstract}
Groundwater has been noted as a major resource for irrigation water in Nepal Terai. The development of different methods of groundwater withdrawal has been promoted in Rupandehi District. Open dug wells were a major source for domestic water use in the 1980s due to cost and ease of construction. But in later years, the promotion of tube wells, access to diesel pump sets, low yield and the deterioration of water quality from the open dug wells have caused a decline in usage and their abandonment in favor of shallow tube wells. This study was conducted in Mahuwari Village, Rupandehi District to assess the feasibility for the rehabilitation of abandoned open dug wells by reassessing access to irrigation water during the dry season, in areas with limited conductivity of aquifer hydrogeology. The yields of the wells were observed to be too low for large-scale irrigation, especially with the rice paddy cropping system. An assessment of well storage and recharge patterns offer an opportunity for off-season supplementary irrigation of home gardens for establishing vegetables and seedlings, with good water management practices. The potential yield of the open dug wells at the peak of the dry season was $4 \mathrm{~m}^{3} \mathrm{day}^{-1}(0.44 \mathrm{~mm}$-ha), suficient to irrigate 0.12 ha of a tomato ield, satisfying $25 \%$ of a currently fallowed field for home gardening.
\end{abstract}

Keywords: Groundwater irrigation; Open dug well; Hydraulic conductivity; AquaCrop

\section{Introduction}

Agriculture in Nepal is a major contributor to the nation's GDP with a contribution of nearly $40 \%$. Of Nepal's 4.21 million hectares (Mha) of arable land area, only $27.7 \%$ is irrigated [1]. Suboptimal water use, especially in the dry season, has been a constraint for increasing the productivity of priority crops [2], eventually having negative consequences to the GDP. Nepal has tremendous groundwater potential to be a viable alternative water source for irrigation in rainfed areas and during the dry period, even in surface irrigated [3,4]. The Government of Nepal (GoN) has a policy to intensify the number of deep and shallow tube wells in Terai in order to provide assured irrigation, but access to groundwater is constrained by the rising diesel prices and an unreliable supply of electricity [5]. A comparative study also showed that farmers in Nepal are in an unfavorable situation for using groundwater because of lack of subsidy and rising fuel costs [6].

The use of groundwater for irrigation is picking up. But it is still substantially underutilized with groundwater irrigation covering only $22 \%$ of the irrigated area [3]. It is estimated that about $4 \%$ of Nepal's renewable water resources are in the form of groundwater in the Terai [7]. Shallow well hydrographs in the Terai show seasonal fluctuations in groundwater, suggesting strong relationships to precipitation and, by extension, to the groundwater recharge.

Rupandehi District is located in the Western Region of Nepal within the Terai zone. With $71 \%$ of the land surface suitable for irrigated agriculture but only $35 \%$ being under irrigation [8], there is substantial potential to increase area under irrigation in dry seasons. The district is characterized by monsoonal rainfall which occurs between June and September delivering an average of $85 \%$ of the total precipitation. Despite its subtropical zoning, the Nepal Terai reaches average temperatures as low as $15^{\circ} \mathrm{C}$ in January and highs of upto $31^{\circ} \mathrm{C}$ in June. Published reports document groundwater table in Rupandehi to vary from 2.5 to $11 \mathrm{~m}$ in the pre-monsoon and 0.6 to $6 \mathrm{~m}$ in the postmonsoon. The presence of open dug wells, shallow tube wells and deep tube wells document the usage of groundwater for domestic, industrial and agricultural purposes [9]. Despite the presence of this shallow groundwater, tube wells have not been sufficiently productive in pockets of Rupandehi District, especially in Mahuwari Village because of the noted low specific yield of the aquifer to sustain the suction of the pumps used by the community households. These aquifers, though, have previously supported open dug wells into which groundwater drained due to gravity, but this gravitational flow had only supported domestic water demands. Due to deteriorating water quality and increased water demands, these wells have generally been abandoned. The wastage of this resource coupled with the increasing poverty and feminization of the community, due to out-migration by male family members, highlights the need to promote more home gardens accessible to the female community members, to improve food security and nutrition by facilitating small irrigated vegetable home gardens, supported by rehabilitation of these wells. This is envisioned to provide a substantial impact on the livelihoods of the community.

As typical for most of the Terai, agriculture in Rupandehi District is dominated by paddy rice and wheat. With landholdings averaging $0.5 \mathrm{ha}$, the promotion of smallholder irrigation systems is presumed to offer the greatest economic and livelihood benefits especially with risk of poorly functioning community-managed systems and structures [10]. It is proposed that developing individual control over the water resource within their reach with proof of economic viability offers a better pathway to their ownership, and efficient and sustainable management.

There is a strong body of existing research outlining the impacts of small-scale water access and management technologies in improving agricultural productivity and economic impacts through increased

*Corresponding author: Okwany $\mathrm{R}$, International Water Management Institute (IMWI), Kathmandu, Nepal, Tel: +977-1-5542306; E-mail.romokwany@gmail.com

Received March 09, 2017; Accepted October 23, 2017; Published November 01,2017

Citation: Okwany R, Prathapar S, Bastakoti CR (2017) Renovating Open Shallow Dug Wells for Off-Season Home Gardening in Nepal Terai. Irrigat Drainage Sys Eng 6: 191. doi: 10.4172/2168-9768.1000191

Copyright: ( 2017 Okwany R, et al. This is an open-access article distributed under the terms of the Creative Commons Attribution License, which permits unrestricted use, distribution, and reproduction in any medium, provided the original author and source are credited. 
farm incomes, improved land productivity and other indirect economic benefits [11-13]. Despite the presence of shallow groundwater aquifers, in some parts of Rupandehi District tube wells are not sufficiently productive because the hydraulic conductivities are too low to release sufficient water under suction created by pumps. However, these aquifers have previously supported dug wells into which groundwater drained due to gravity as these received enough water for domestic use. Later, the wells were abandoned for various reasons but mainly because of the drudgery of bucket lifting and the low yield under pumping. But, poverty being a continuous phenomenon, and feminization of agriculture increasing, seeking agriculture near the household offers a chance to reduce the food poverty while offering the women farmers an opportunity to operate closer to their homes. Therefore, rehabilitating these wells to provide irrigation water will improve the livelihoods of these communities.

With this background, a study to assess the potential for developing household irrigation units by utilizing the water resources available from currently abandoned shallow dug wells (SDW), was carried out in Mahuwari Village, Rupandehi District. With no irrigation infrastructure, the village relies on rain-fed agriculture suplemented by river-pumped irrigation on fields within reach of the local river. Existing open SDW have not been fully utilized and have generally been abandoned since yield and capacity are too low to sustain the typical paddy-growing system of the community. The presence and preference for hand-pumped shallow tube wells for domestic use has reinforced this trend.

In this paper, we present the results of our yield and capacity assessments of SDW and present the technical conditions under which economic use of these water resources can be rehabilitated and accessed for agricultural use.

\section{Study Site}

Rupandehi District lies within the Western Development Region of Nepal in the southwestern Terai. The district covers an area of $1,360 \mathrm{~km}^{2}$ divided into 71 Village Development Committees and Municipalities [8]. The district is headquartered in Siddharthanagar (Bhairahawa). The study was located in Mahuwari Village in Lumbini VDC (Lat. $27.4^{\circ}$; Lon. $83.2^{\circ}$ ). The village is situated about $25 \mathrm{~km}$ to the southeast of Bhairahawa (Figure 1).

The district is formed of three basic geological formations ranging from the siwaliks to the north and into the Bhabar zone and Gangetic plain in the south [2]. The result is a hydrogeolocical structure facilitating variable aquifer potentials from low-yield aquifers, shallow/perched aquifers as well as artesion flow areas. The hydraulic movement and potential of groundwater yield in the aquifers are thus dependent on the aquifer characteristics (transmissivities and gradient configurations).

The development of groundwater, especially through deep tube wells, has been implemented as early as 1973 with the BhairahawaLumbini Groundwater Irrigation Project (BLGWP), with several subsequent groundwater development projects too being implemented. The BLGWP was intended to bring 20,000 ha land under irrigation through 175 deep tube wells installed under the project. The current estimate is that over 43,000 ha out of over 88,000 ha of irrigable agricultural land are being irrigated through groundwater resources [2].

The study site is on an area hydrogeologically categorized as soft formation (heavy clays) with marginal yield due to low conductivity and transmissivity; due to predominance of fine-grained sediments of

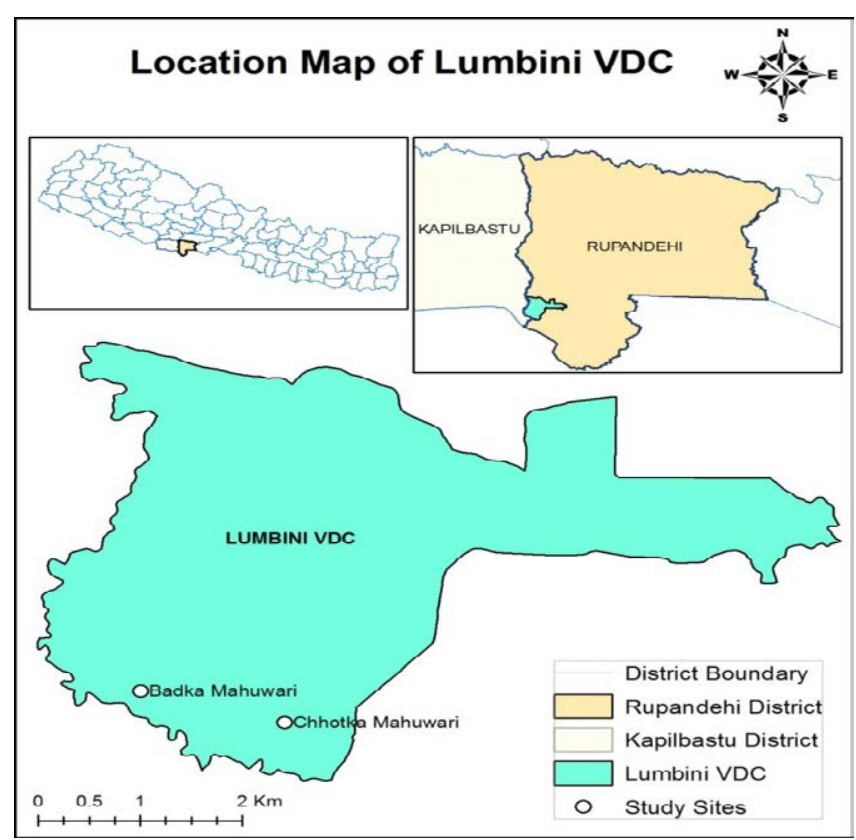

Figure 1: Location map showing the study sites.

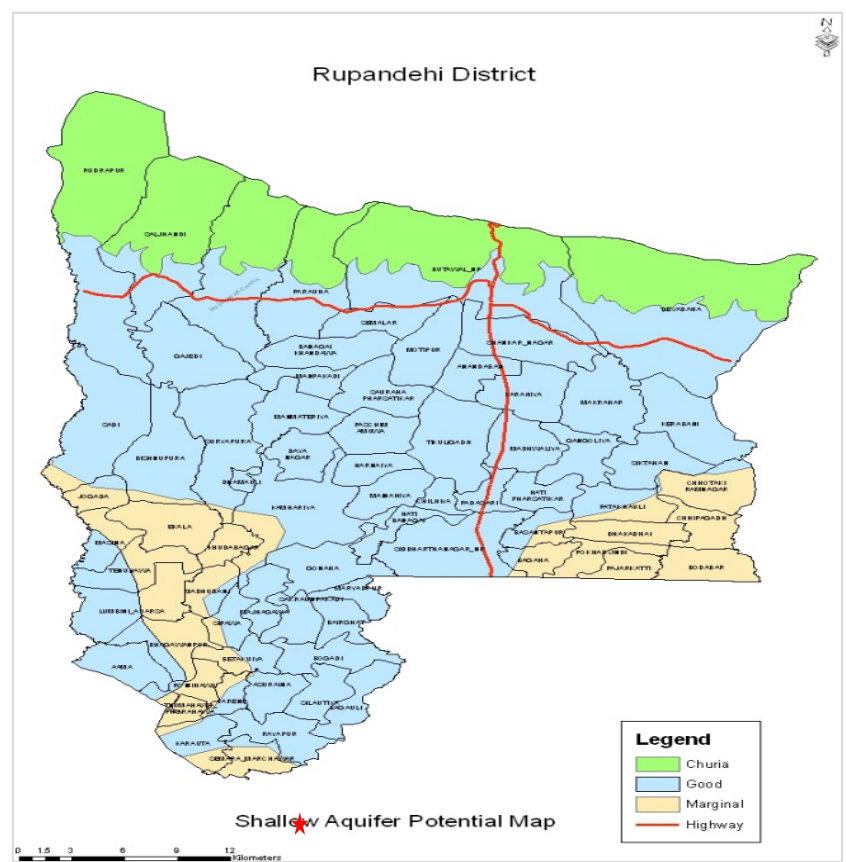

Figure 2: Groundwater potential map of Rupandehi District (Shah et al., 2013) red star marks the generalized study location.

the lower Bhabar zone (Figures 2 and 3). The recovery of the wells in the area was also found to be too slow to sustain the pumping demand for standard irrigation.

\section{Methodology and Data}

This study was developed following an initial scoping study and community survey in Mahuwari Village, that identified low storage capacity and low yield of shallow dug wells to meet the existing pumping systems and need for the farmers. The prevalence of $3.73 \mathrm{~kW}$ diesel pumps with pumping rates of $24 \mathrm{~m}^{3} / \mathrm{h}$ was noted. The initial surveys 


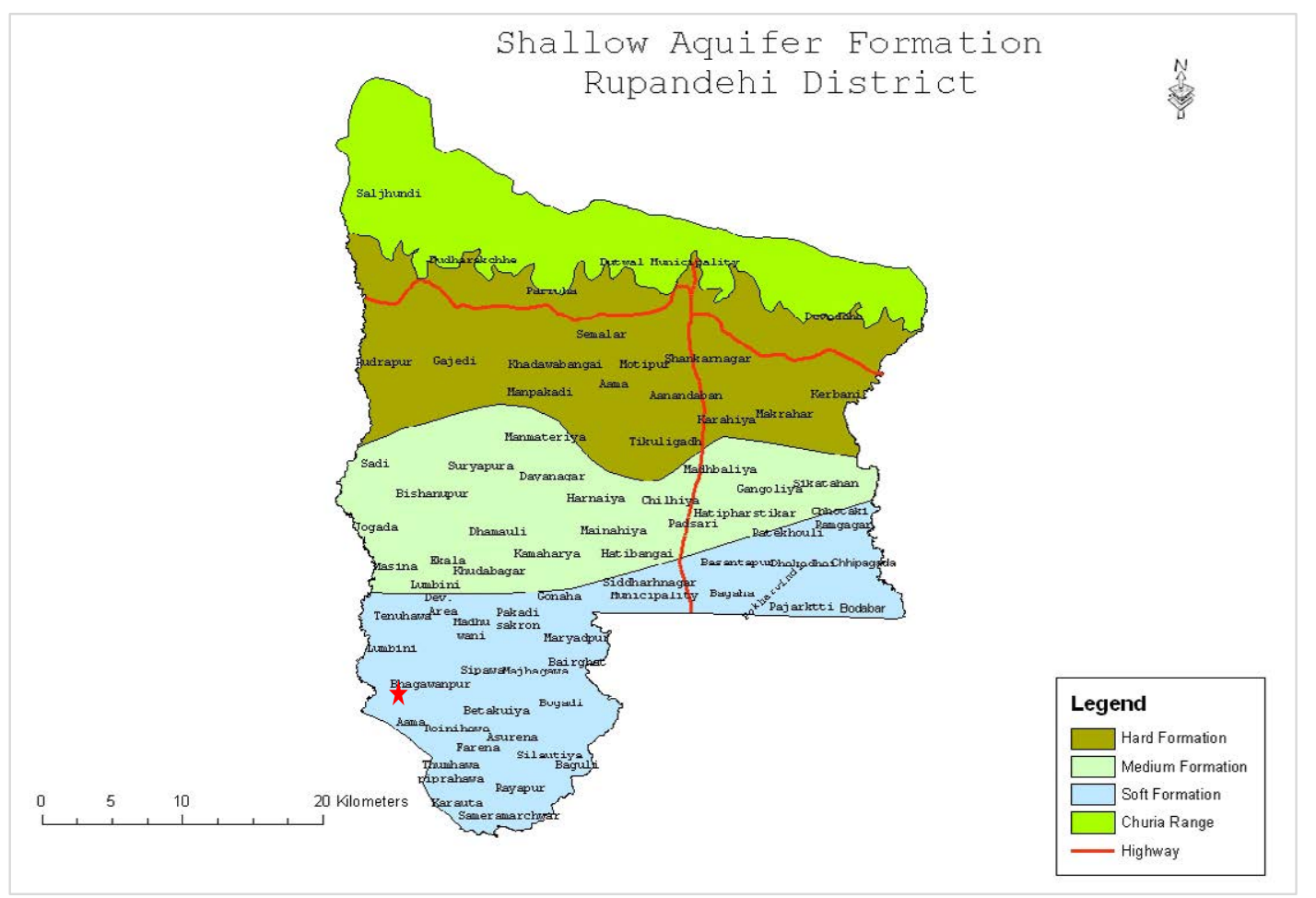

Figure 3: Zonation of Rupandehi District based on aquifer material for shallow tube wells (Shah et al., 2013); red star marks the generalized study location.

found that the use of this capacity of pumps drained the dug well water in under 30 minutes and were thus considered insufficient for farmer requirements. The constraint of low yield was found to impact these shallow dug wells located in areas with fine-grained sediments of the lower Bhabar zone [2]. Based on these observations a sample of three wells was selected from within the community for pumping tests. The selected dug wells were first cleaned and physical dimensions recorded. The static water level before testing was measured as well as the depth of water storage in the well. A pumping test was performed using a locally supplied diesel pump and the rate of discharge and the rate of fall of the storage head were determined. After complete drainage of the storage head the loose silt, clay and organic matter deposits on the bottom of the well were dredged to obtain an effective depth of the well and as preparation for monitoring the recovery of the well.

The recovery of the storage of the well head was monitored until a stable static head was achieved to determine total recovery time, as well as the rate of recovery. The well pumping and recovery tests were thus designed to help in the determination of the direct and indirect characteristics of the well and the aquifer, relevant for yield and capacity estimations for the shallow dug wells and the local aquifer.

Based on the yield of the well and capacity determined, climatological conditions of the area and the cropping patterns, a net irrigation requirement was modeled using AquaCrop [14]. By limiting the irrigable area to the available pumpage potential of the open dug wells based on irrigation demand, a gross irrigable area was estimated based on an irrigation efficiency of $70 \%$.

\section{Results}

\section{Characteristics of selected dug wells}

The physical and structural dimensions of three sample wells were taken with special consideration of those wells located within close proximity to irrigable fields. The static groundwater level (meters below ground level [mbgl]) was monitored on two wells from the two hamlets of the Mahuwari Village, for the period spanning the end of the monsoon and the post-monsoonal season, to determine the temporal variability of the shallow groundwater table to seasonal changes in precipitation. Pumping tests on the abandoned shallow dug wells were performed for three wells distributed around the village (Table 1) in February 2014.

All wells in the community are brick-lined with diameters ranging from 1.3 to $1.8 \mathrm{~m}$. The wells were found to have depths ranging from 6 to $9 \mathrm{~m}$. The shallower wells are generally thought to be due to accumulation of deposits at the bottom. The wells thus provide potential dry-season storages of 3 to $10 \mathrm{~m}^{3}$ depending on diameter and present storage depth.

Using the predominant $3.73 \mathrm{~kW}$ diesel pumping units, pumping rates between 16 and $19 \mathrm{~m}^{3} / \mathrm{h}$ were recorded. At these pumping rates, the wells were completely drained in durations ranging from 5 to 5 minutes; hence, the farmers' perspective of unsustainability of the wells for agricultural purposes. This supports the results of a 2002 field survey on problems facing irrigators in Rupandehi [9] that noted low yield and drying of wells during pumping as constraints to irrigation using shallow dug wells.

\section{Weekly changes to groundwater levels in two adjacent villages}

The result of weekly monitoring of two wells (Figure 4), shows the seasonal changes in the water table levels for the duration of highest irrigation demand. The plot of the dug well at Badka Mahuwari shows the response to intensive pumping for irrigation on this well. It is noted that the wells achieve a stable static groundwater level towards the end 


\begin{tabular}{|c|c|c|c|}
\hline Description & Well no. 1 & Well no. 2 & Well no. 3 \\
\hline \multicolumn{4}{|l|}{ Location } \\
\hline Latitude, degree & 27.439 & 27.440 & 27.435 \\
\hline Longitude, degree & 83.226 & 83.225 & 83.240 \\
\hline Well diamater, $\mathrm{m}$ & 1.32 & 1.32 & 1.71 \\
\hline Well depth, $\mathrm{m}$ & 8.23 & 6.25 & 7.01 \\
\hline Water table, mbgl & 5.08 & 2.83 & 3.02 \\
\hline Water depth, $\mathrm{m}$ & 2.84 & 3.41 & 3.99 \\
\hline Dry season storage, $\mathrm{m}^{3}$ & 3.90 & 4.68 & 9.14 \\
\hline \multicolumn{4}{|l|}{ Pump discharge rate } \\
\hline Pumped depth, $m$ & 2.82 & 2.70 & 0.90 \\
\hline Pumped volume, $\mathrm{m}^{3}$ & 3.87 & 3.70 & 1.57 \\
\hline $\begin{array}{l}\text { Pumping duration, s } \\
\text { (second) }\end{array}$ & 840 & 725 & 325 \\
\hline Pumping rate, $\mathrm{m}^{3} /$ minute & 0.28 & 0.31 & 0.29 \\
\hline
\end{tabular}

Table 1: Characteristics of three sample open shallow dug wells in Mahuwar Village, Rupandehi District, Nepal (February 2014).

Monitoring date, $\mathrm{dd} / \mathrm{mm} / \mathrm{yy}$

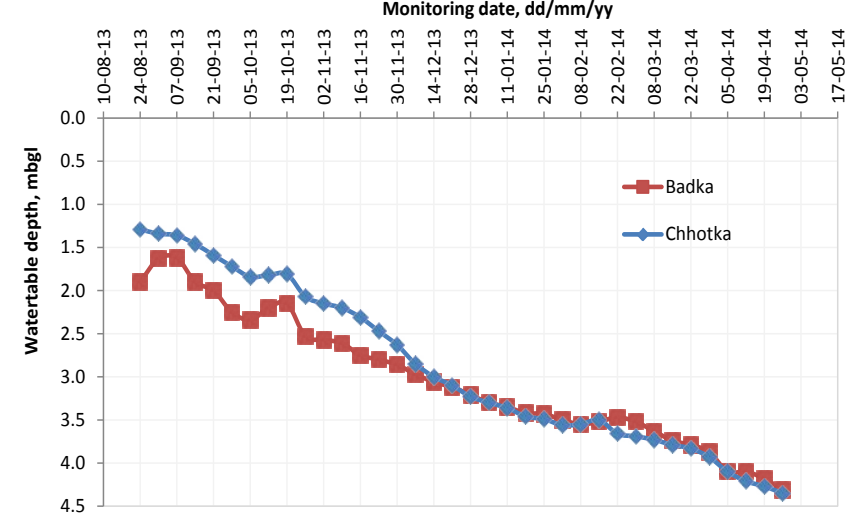

Figure 4: Static groundwater level at Badka and Chhotka hamlets, Mahuwar Village for the period August 21, 2013-April 26, 2014.

of January at about $3 \mathrm{mbgl}$, showing the temporal duration at which spatial variability between the two hamlets occurs. In addition to the temporal monitoring of the three sample wells, a spot determination of eight wells in the community was made in February 2014 with recorded static groundwater levels ranging between 3.1 and $3.6 \mathrm{mbgl}$.

Following the complete draining of the wells, the recovery of the dug wells was monitored (Figure 5) and the rate of storage head recovery was recorded. It is shown that the recovery of the static head in the wells after complete pumping required 5 to 8 hours. This further confirms the observed low hydraulic conductivity of the aquifer. However, recovery within a day indicates that irrigation of small parcels of land may be carried out daily.

\section{Hydraulic conductivity}

An assessment of the wells in the village indicated no drawdown interaction with neigboring wells even at short distances of $50 \mathrm{~m}$. The study was thus unable to use the regular pumping test equations that require observation wells without installation of the same. We therefore indirectly evaluated the hydraulic conductivity using the head recovery data and by applying Hvorslev Slug Test method for hydraulic conductivity testing [15]. The hydraulic conductivity of each of the three wells was determined as $1.32,2.34$ and 0.23 meters/day, respectively.

\section{Irrigation water requirement}

To further assess the capacity and practical impact of these wells, an irrigation water demand assessment was made using AQUACROP modeling of the crop water requirements given the existing resources to determine the impact of the dug wells as an extra water source.

Rainfall (Figure 6), temperature (Figure 7), relative humidity (Figure 8) and wind speed (Figure 9) were obtained for Bhairahawa Agricultural Station Index 707 [16-19]. The CROPWAT program was then used to estimate the reference crop evapotranspiration (Figure 10) for the study location based on the climatological data collected at Bhairahawa Agricultural Station.

To evaluate the irrigation water requirements in Mahuwari village, AquaCrop program was run for the "Net Irrigation Requirement", assuming current water management system for paddy rice-wheat tomato and paddy rice - cauliflower - tomato crop rotations. The crops' evapotranspiration and net irrigation demands across the complete cropping rotation are presented in Figure 11. The main irrigation demand is recorded between November and May with peak irrigation demand in April/May. The period between June and October is shown to be satisfactorily watered from the monsoonal rains.

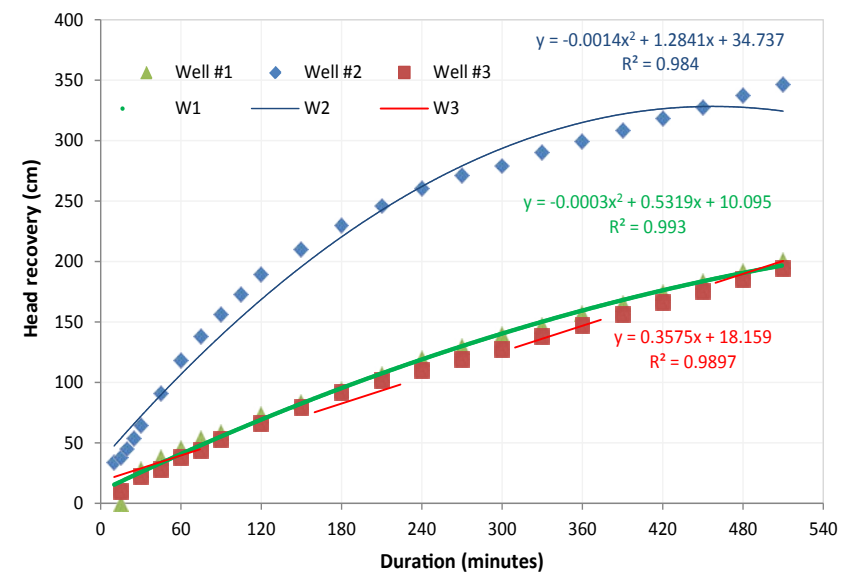

Figure 5: Recovery plot of the pumped-out open dug wells: Wells (no. 1 and no. 2) are located in Badka Mahuwari, whereas Well no. 3 is located in Chhotka Mahuwari.

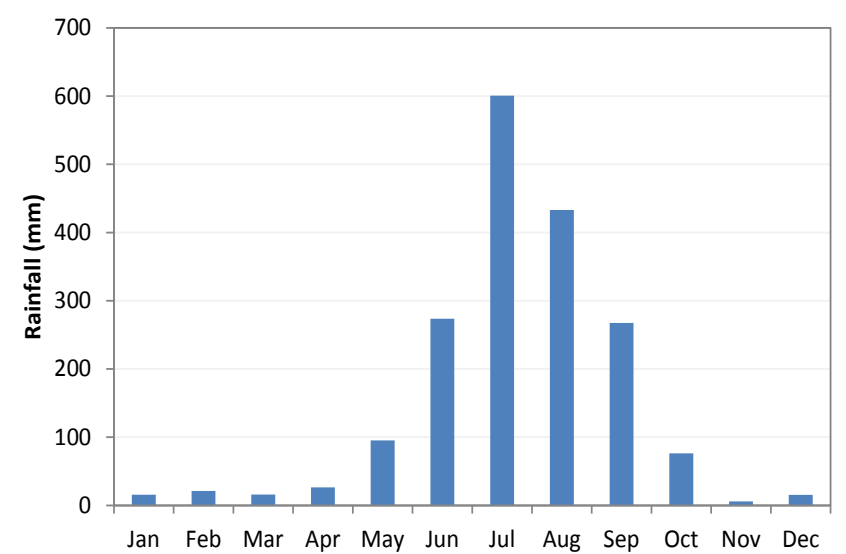

Source: Meteorological Records of Nepal, DHM.

Figure 6: Rainfall, Bhairahawa, Nepal (30-year average, 1983-2012). 


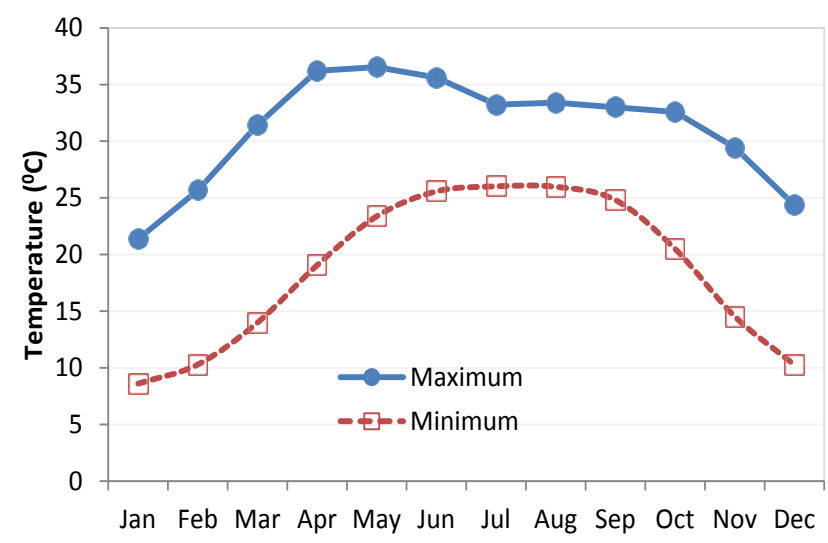

Source: Meteorological Records of Nepal, DHM.

Figure 7: Temperature, Bhairahawa, Nepal (30-year average, 1983-2012).



Source: Meteorological Records of Nepal, DHM

Figure 8: Relative humidity, Bhairahawa, Nepal (30-year average, 1983-2012)



Figure 9: Wind speed, Bhairahawa Agric Station 707, Nepal (12-year average).

Towards assessing the specific potential use of a sample of open dug wells for irrigation in Chhotka Mahuwari, an irrigation scheduling was modelled using AquaCrop program. The net irrigation demand



Figure 10: Reference evapotranspiration, ETo, for Bhairahawa Agricultural Station based on meteorological average records of 1983-2012, computed by CROPWAT version 8.0, FAO (Raes, D., 2009).

(assuming 100\% on-farm irrigation application efficiency) was weighted against the optimal water supply from a sample well.

To estimate the irrigation potential of the open dug wells the following procedure was followed:

1. A daily average supply from the open dug well was computed for each month.

2. Daily average net irrigation demand by the crop was determined for each crop, for specific rotations assessed; eliminating months with sufficient rainfall (Figure 11).

3. Using the open dug well supply gross irrigable area was plotted for each month in the rotation (Figure 12).

4. With variable gross irrigation potential, Figure 12 provides a visual guide against which an optimal choice of irrigable area can be determined with consideration of water application efficiency and/or deficit irrigation decisions.

It is shown that irrigation will be required only for the pre- and postmonsoonal seasons (Figure 12), with greatest irrigations being required for the pre-monsoonal crops. The landholding in this community is characterized with land sizes less than 1 ha for the majority of farmers; but with average landholding size being 1.2 ha, land is thus not a limiting resource in agricultural productivity of the study site. With water as the limiting factor, an optimal irrigable area using open dug wells as the only irrigation water source, was estimated for the two model rotations. The results show potential irrigation for 0.1-0.2 ha/ well. The irrigated area can be potentially increased with improvements in on-farm irrigation efficiency.

\section{Conclusions}

The rehabilitation of the shallow dug wells offers farmers in Mahuwari an opportunity for scheduling their irrigation, making choices between different crops and further diversifying the cropping patterns away from the paddy rice-wheat system currently being practiced.

The computed hydraulic conductivity of the test wells show variabilities even for the short spatial separation within the village. The variability of the aquifer properties reflects the nature of the Terai, which is characterized by colluvial deposits of clay and silts with highly irregular and localized sedimentation. 

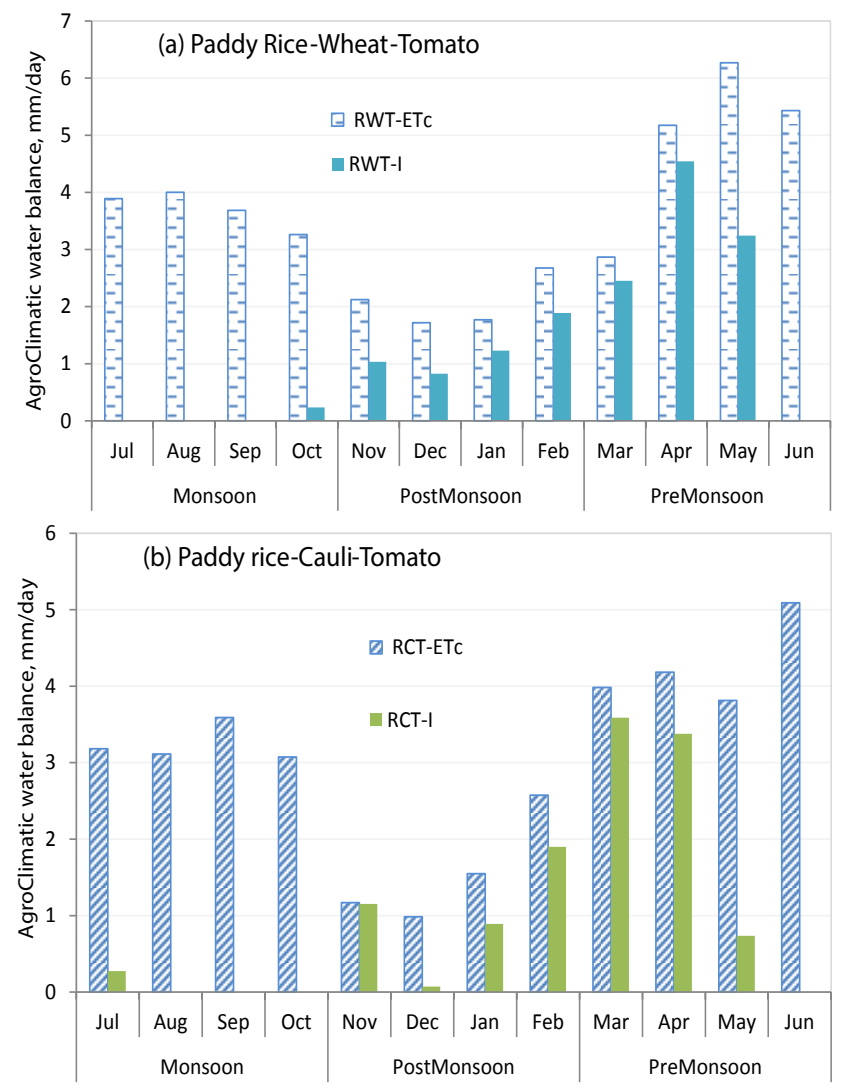

Figure 11: a) Monthly averages for agroclimatic crop water balance (ETc-crop water requirement; I-irrigation requirement) for Paddy Rice-Wheat-Tomato (RWT) and b) Paddy Rice-Cauliflower-Tomato (RCT) crop rotations at Chhotka Mahuwari Village, Rupandehi District, Nepal.

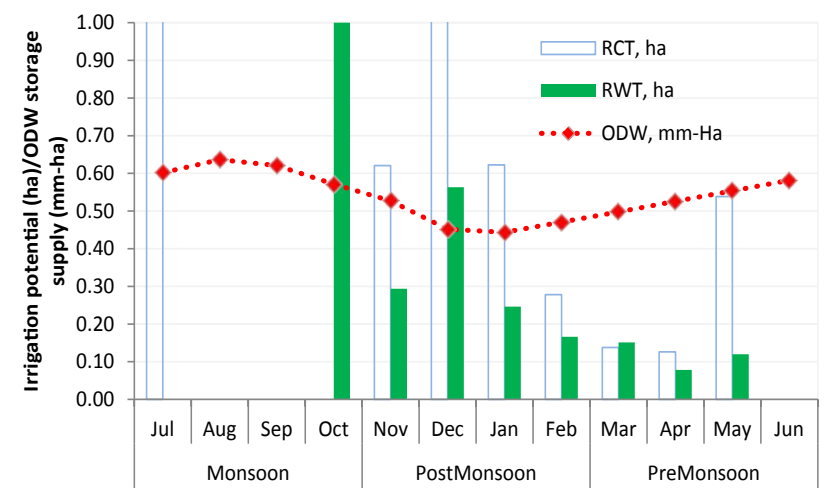

Figure 12: monthly averages of daily irrigation water yield from the open dug well as well as the gross irrigation potential based on the open dug well water supply generated by fitting the supply (ODW supply) and demand (ETc) levels for the crops to determine the potential irrigable area for each month.

The presence of a substantial number of wells in the community offers an underutilized water resource especially in the post-monsoonal and winter seasons. The community highly values groundwater for irrigation [9] though in recent times due to the perceived low yield of the shallow dug wells, much of the interest is on the tube wells available. With greater on-farm water management capacity it is projected that the abandoned open shallow dug wells would significantly increase onfarm productivity and cause a general net addition to farmers' annual output, through productive use of the normally fallow fields in the dry seasons. It would also facilitate increased involvement of women farmers in agriculture, required because of increasing out-migration of the male labor force. It is shown that the wells offer enough water storage for irrigating from 0.1 to 0.2 ha of land, which is larger than an average home garden in Rupandehi District [18]. This potential can be further enhanced by implementing more efficient irrigation systems especially through promotion of home gardening, which could result in increased production and consumption, thereby enhancing family nutrition. Given the average landownership of about 0.5 ha per household [9] it is noted that this resource is enough to maintain up to $25 \%$ of household farmland, with year-round agricultural production for the farmer households that privately own wells. This is not only an economic use of the resource but can significantly contribute to domestic food security and nutritional benefits.

A random survey of shallow tube wells in the community suggests that groundwater withdrawal is still at infancy in this village, as no significant decrease in tube well yields or significant reductions in water table have been noted. It is thus supposed that increased utilization of open dug wells will not have any major impacts on the groundwater yield based on the projected demand for home gardening. It was also observed that the seasonal monsoonal flooding in the area is sufficient to fully recharge the shallow aquifer with a number of areas experiencing seasonal artesian flow regimes, reflecting the impact of groundwater recharge to both the shallow aquifer relevant to the open dug wells and the deeper aquifer accessed through the shallow and deep tube wells. Despite these observations, further studies are suggested to further assess the spatial hydrogeology of the area and thus a clearer understanding of the aquifer properties for a long-term determination of groundwater sustainability.

This study thus proposes that with technical and logistical support to individual farmers from the district administration, the farmers can be encouraged to rehabilitate this available resource for economic production. Such small private irrigation can have significant impact on farmer earning and greatly contribute towards poverty alleviation.

\section{Recommendations}

The rehabilitation of open dug wells in Mahuwari village will contribute to maintaining year-round agricultural activity. It will provide needed irrigation water for existing home gardens which lie fallow from shortage of water, providing food and income from the growing of vegetable crops. Increased farmer awareness of better management of the wells will enhance their optimal use, without undue risk of lack of water when needed. Awareness of irrigation technologies, which are water-efficient but simple, will further increase the potential irrigable area.

\section{Acknowledgements}

This study was funded by the Climate Change, Agriculture and Food Security (CCAFS) and Water, Land and Ecosystems (WLE) research programs of the Consultative Group on International Agricultural Research (CGIAR) to which the authors are most thankful.

\section{References}

1. http://www.worldbank.org/en/results/2014/04/11/nepal-irrigation-and-waterresource-management

2. Shah S, Shrestha SR, Shrestha S (2013) Status of shallow tube wells irrigation and shallow aquifer in Rupandehi District. Kathmandu Nepal: Groundwater Resources Development Board (GWRDB).

3. ADB (Asian Development Bank) (2012) Shallow tube well irrigation in Nepal Impacts of the community groundwater irrigation sector project. Manila Philippines. 
Citation: Okwany R, Prathapar S, Bastakoti CR (2017) Renovating Open Shallow Dug Wells for Off-Season Home Gardening in Nepal Terai. Irrigat Drainage Sys Eng 6: 191. doi: 10.4172/2168-9768.1000191

4. NADS (Nepal Agricultural Development Strategy) (2012) Irrigated agriculture and water resources component Water Resources Assessment Report ADB TA 7762-NEP. Kathmandu Nepal: Nepal Agricultural Development Strategy.

5. Pant D, Samad M (2010) Synthesis of IWMI work in Nepal. IWMI 138.

6. Shah T (2007) Groundwater economy of South Asia: An assessment of size significance and socio-ecological impacts. The agricultural groundwater revolution: Opportunities and threats to development, pp: 7-36.

7. Sharma CK (1995) Shallow aquifers (Phreatic) in Nepal.

8. VDC (Village Development Committee) (2012) Village Development Committee and Demographic Profile of Nepal 2013: A socio-economic development database of Nepal. Kathmandu: Mega Publication and Research Centre.

9. Pant D, Belbase M (2003) Socio-ecological implications of groundwater in Nepal. IWMI-TATA Annual Partners' Research Workshop.

10. Malik R, Giordano M, Sharma V (2014) Examining farm-level perceptions costs and benefits of small water harvesting structures in Dewas Madhya Pradesh. Agricultural Water Management 131: 204-211.

11. Shah T, Alam M, Kumar MD, Nagar RK, Singh M (2000) Pedaling out of poverty: Social impact of a manual irrigation technology in South Asia. IWMI 45.

12. Dillon A (2011) Do differences in the scale of irrigation projects generate different impacts on poverty and production? Journal of Agricultural Economics 62: 474-492.

13. Burney J, Naylor RL (2012) Smallholder irrigation as a poverty alleviation tool in sub-Saharan Africa. World Development 40: 110-123.

14. Raes D, Steduto P, Hsiao TC, Fereres E (2012) AQUACROP: Reference manual.

15. Campbell MD, Starret MS, Fowler JD, Klein JJ (1990) Slug tests and hydraulic conductivity. In Proceedings of the "Petroleum Hydrocarbons and Organic Chemicals in Groundwater: Prevention, Detection, and Restoration"-conference NWWA pp. 85-99.

16. DHM MR (2014) Personal communication. Babarmahal Kathmandu Nepal: Department of Hydrology and Meteorology.

17. Rao GK, Shrestha R, Vaidya YL (1993) Hydrogeological conditions in the Tera Plain of Rupandehi District Lumbini Zone Nepal with special emphasis on groundwater. In Subsurface-Water Hydrology pp. 131-149.

18. Sunwar S, Thornstrom CG, Subedi A, Byrstrom M (2006) Home gardens in western Nepal: Opportunities and challenges for on-farm management of agro biodiversity. Biodiversity and Conservation 15: 4211-4238.

19. Polak P, Yoder R (2006) Creating wealth from groundwater for dollar-a-day farmers: Where the silent revolution and the four revolutions to end rural poverty meet. Hydrogeology Journal 14: 424.
Citation: Okwany R, Prathapar S, Bastakoti CR (2017) Renovating Open Shallow Dug Wells for Off-Season Home Gardening in Nepal Terai. Irrigat Drainage Sys Eng 6: 191. doi: 10.4172/2168-9768.1000191 